\title{
The Concept of Accountability in Good Governance
}

\author{
Khotami \\ Student Doctoral Program of Government Sciences Padjadjaran University, Indonesia \\ Lecturer in Government Science Islamic University of Riau \\ E-mail: khotami.ip@soc.uir.ac.id
}

\begin{abstract}
Accountability is a form of liability that refers to who and for what and what is accountable, which is understood as the obligation of the holder of the trust to provide accountability, presenting and reporting all activities that are his responsibility to the party who provides the trust has the authority to hold such accountability. The decision-makers of the government, the private sector, and community organizations are accountable to the public and to the agencies concerned. The form of liability depends on the type of organization concerned. Accountability basically provides a very important role in creating a good governance activity as a part of improving public confidence in government performance. The conception of accountability can be seen that government officials are not only accountable to higher authorities in the institutional chain of command but also accountable to the general public, non-governmental organizations, mass media, and many other stakeholders. Public accountability consists of two kinds, namely (1) vertical accountability and (2) horizontal accountability. Vertical accountability is accountability for the management of funds to higher authorities, such as accountability of work units to local governments, regional accountability to the central government, and etcetera. And then horizontal accountability is the responsibility that is conveyed to the general community. In this paper, the research method used is literature study or literature review. According to the concept of good governance that to create a good governance, it is necessary cooperation between important components that include government as the holder of power, society as a social element and the private sector as a partner of the government. Therefore, the government as the holder of power that gains legitimacy from the state has the responsibility to create the general welfare through the organs of the government concerned.
\end{abstract}

Keywords - accountability, good governance.

\section{INTRODUCTION}

As one of the efforts in creating a good governance can be done by utilizing the maximum government resources. In addition to effective, efficient, efficient and effective management of government components. Governments are required to be responsive, participative and professional in carrying out basic tasks and functions for the sustainability of government. The need for information about the implementation of government is actually necessary to ensure public openness about how the process of making, implementation and results achieved by the government in every government activity. Therefore, the principles of transparency, accountability, responsiveness, and professionalism in creating better governance conditions need to be applied consistently and continuously. Therefore, cooperation between the government, the public, and the private sector is required. One of the important things of the existence of such cooperation is the availability of publicly accessible information, which demands the government's role so great in maintaining public trust. Accountability is one of the steps that must be taken to maintain and increase public confidence in government performance. Talking about accountability is defined as the ability to provide answers to higher authorities over the actions of a person/group of people to the wider community within an organization [1]. Accountability is a complex concept that is more difficult to achieve than eradicate corruption. Therefore, accountability needs to be interpreted as a continuous, consistent and transparent process in creating better organizational conditions.

Accountability in the context of public administration is always interesting to examine because the center of government administration practice lies precisely in issues surrounding accountability [2]. In European countries, for example, accountability has long been a concern especially in relation to policy-making. Accountability is a concept that is constantly evolving and often used because it provides an image of transparency and trust for those who run it. So, accountability can be interpreted as an evaluation activity of the implementation process of organizational performance to be accountable so that it becomes a feedback for organizational leadership in the future.

In modern public administration, accountability is king, and measurable results are a necessity [3]. Then, the question is how to determine precisely the concept of accountability. Appropriate understanding allows determining what aspects are taken into account to assess the accountability of the stakeholders. Therefore, the first problem is the conceptual problem. Conceptually it means that what is meant by accountability. Accountability is often used in a rather broad sense, for example, often equated with the concept of evaluation, but the essence of accountability is a concept that can be synchronized with responsiveness, responsibility, and effectiveness. The next question is related to an analysis that includes a discussion of accountability. When translated from a simple definition, accountability is defined by a series of dimensions to describe the various relationships of accountability and their composition within different domains of governance.

The word accountability originally came from the AngloNorman language, and not from the Anglo-Saxon. Historically and semantically the word accountability is closely related to the word accounting (accounting) which literally means bookkeeping. In political discourse, accountability no longer carries a rigid bookkeeping image and financial administration but carries a promise of justice and propriety. Accountability does not refer to the king to judge, but on the contrary that the authority of the king is accountable to his people [4]. As noted above, that true accountability is the authority that the king has 
in order to be accountable to the people. Even more than that, accountability comes to the political promise through the vision and mission submitted by the leaders of the organization. At the end of the twentieth century, the form of accountability moves from the understanding of financial accounting to public accountability and runs parallel with the emergence of a new public management approach by the Margaret Thatcher and Reinventing government. In today's political science and the discourse of scholars, accountability is often the conceptual basis that encompasses various different kinds of concepts. it is used as a synonym for various needs of political definitions such as transparency, justice, democracy, efficiency, responsiveness, responsibility, and integrity [5]. The government initiated by the Clinton and Gore governments of the United States. Both forms of reform introduced the management style and private instruments into the public sector.

\section{DISCUSSION}

\section{The Meaning of Accountability in Good Governance}

The term "governance" is basically meant to illustrate a broader concern, but the term is inappropriately and unanimously agreed upon, and this is seen when we assess a set of definitions used by different public bodies. The word good governance in the definition of politics was first used by the Department for International Development (formerly development of administration outside the UK) under the label "good government". It is composed of four main components. First, the legitimacy that implies that the system of government must proceed with the government's approval, therefore the government has the means to give or not to give consent; secondly, the legitimacy seen in the UK's policy document is guaranteed by pluralists and multi-party democracy. Accountability includes the existence of mechanisms where there is certainty that public officials and political leaders are responsible for their actions, responsible for the use of public resources and transparency of government and media freedom. Have the competence to make and run the right public policy including the ability to deliver the service to the public efficiently.

Despite its centrality to democracy, accountability has not accumulated "a substantial tradition of academic" analysis, and there is "little agreement" over its "general nature or its various mechanisms". Most scholars discussing accountability never define it, and the available definitions vary greatly. In an influential definition, Bovens defines accountability as "a relationship between an actor and a forum, in which the actor has an obligation to explain and to justify his or her conduct, the forum can pose questions and pass judgment, and the actor may face consequences."The effects of such relationships are considered distinct from accountability itself. This article defines accountability more broadly. For the purposes of this article, accountability occurs when a government or a semistate actor takes action in response to behavioral requirements to describe and to justify conduct, communications from others about their responsibilities, or other relevant information, such as data about policy effects [6].

Another definition given by the United Nations Development Program (UNDP, 1995) is to distinguish the label from the word 'governance'. While the principles of governance remain the same, and there are only two significant variations of meaning. First, UNDP is less emphasizing the assumptions of pluralist, multi-party superiority, electoral-oriented systems, the recognition that forms of political authority can combine efficiency and accountability in different ways. Second, recognizing that there is a problem of cultural values and that governance systems may vary in response to differences in the order of values placed on economic, political, and social relationships, giving differences in the weight of ideas such as participation, individuality, command, and authority. The last example used by the World Bank, which jumps from the neutral label 'governance' to 'good governance'. According to World Bank documents, good governance initially places greater emphasis on predictable policy openness and policy-making, professional policy and capability management, and effective use of resources to achieve improved levels of social and economic development. but the conditions still require strong community participation, clear implementation within the rule of law, so that the World Bank can not refuse to jump in the direction of political (and controversial) territory; and nearly half of government borrowing between 1991-1993 was a project with an inevitable political connotation (world Bank, 1994) [7].

Good and clean government is also an important part of good governance. That means the government must be free from the implementation of Corruption, Collusion, and Nepotism (KKN) [8]. In line with the wider and deeper involvement of the government in various public service policy making processes and their implementation, the more activities and measures of government bureaucracy are increasing. In addition, government bureaucracy is still burdened with the execution of the tasks of traditional government, namely maintaining the law and public order, as well as build the various infrastructure needed by the community. Today's the government is also called to address broader issues such as the education, health and social welfare sectors. This situation positions the bureaucracy as a central player in serving the various needs of the public, from formulating and policymakers, as agents of social change, development agencies, managers to crises, social workers, intermediaries of interest brokers, public relations officers relations expert), regulatory of various economic commodities, to become spokespersons of various interest groups [9].

Meanwhile, the term good governance in the Indonesian language is often less satisfactory because of the difficulty of finding the exact match. Bondan Winarno once offered the word "organizing" as a translation of the word governance, but was deemed inadequate to represent the substance of the true meaning of the term governance. So it is concluded that the term good governance is often understood as "good government/governance", essentially refers to a series of actions, facts or governing behavior that direct or control or influence public affairs within a country (A.S. Horby 1995: 515) [10].

According to Taschereau and Campos that good governance is a condition that guarantees the process of alignment, equality, cohesion, and balance of role, the existence of mutual control is done by the components of government, people or civil society and entrepreneurs who are in the sector private [11]. 
In the context of government organizations, public accountability is the provision of information on the activities and financial performance of the government to the parties concerned with the report.

\section{The Types of Accountability}

According to Mardiasmo [12], public accountability consists of two kinds, namely:

1. Vertical accountability is accountability for the management of funds to higher authorities, such as accountability of work units (Dinas) to local governments, accountability of local governments to the central government, and accountability of the central government to the Parliament.

2. Horizontal accountability is the responsibility of the Government and the Regional Government to the DPRD and the wider community.

According to LAN and BPKP (LAN and BPKP: 2000), performance accountability is the obligation to provide accountability or answer and explain the performance and actions of an organization legal person/chairman to a party who has the right or authority to request information or accountability. In implementing accountability within government agencies, it is necessary to consider the following principles:

1. Should be commitment and leadership of all staff of government agencies. Need to manage the implementation of mission to be accountable

2. Should be a system that can ensure the use of resources consistently with applicable laws and regulations

3. Must be able to show the level of achievement of goals and objectives that have been set.

4. Should be honest, objective, transparent and active as a catalyst for change of management of government agencies in the form of updating methods and techniques of performance measurement and accountability reporting

5. Must be oriented towards achieving the vision and mission and the results and benefits obtained.

In the course of bureaucracy the succe, the accountability of a government agency is the embodiment of the obligation of government agencies to account for ss or failure of the mission implementation of the relevant institution. The following will be discussed more accountability.

\section{Character of Accountability}

In the administration of government, accountability can not be known by the people without the government notify him in connection with information related to the collection of resources and sources of public funds and their use. Accountability seen from a functional perspective is a level with five different stages starting from a stage that requires more objective measures at a stage that requires a subjective measure. The stages are:

a. Probability and legality accountability that is the accountability of the use of funds in accordance with the approved budget and in accordance with applicable legislation. b. Process accountability that is accountability that uses processes, procedures, and measures in carrying out the specified activities.

c. Performance accountability is to see whether the activities performed are efficient.

d. Accountability program that highlights the determination and achievement of goals that have been set.

e. Policy accountability is the stage of selection of various policies that will be applied or not.

Most countries that adhere to democracy, true sovereignty is in the hands of the people. Government as an institution that is given legitimacy in running and regulating people's lives through the rules and taking and using the source of the fund from the people, must give responsibility to all its activities to society. If seen in the implementation of the community curiosity is not only limited to information related to finance but more than that, people want to know more whether the government has worked in an economical, effective and efficient.

\section{Dimensions of Accountability}

The dimensions of accountability that must be met by public institutions include (Hopwood and Tomkins, 1984, Elwood, 1993) [13].

\section{a. Accountability Law and Honesty}

Legal and honest accountability is the accountability of public institutions to behave honestly in their work and to comply with applicable legal provisions. Legal accountability demands law enforcement, whereas honest accountability demands healthy organizational practices, malpractices, and administrative malls.

b. Process Accountability

Accountability processes associated with procedures used in performing tasks are good enough in terms of adequacy of accounting information systems, management information systems, and administrative procedures.

c. Program Accountability

The program's accountability is concerned with whether the objectives set out are achievable or not and whether the organization has considered alternative programs that provide optimal results for a minimal cost.

d. Policy Accountability

Policy accountability relates to public institutions' accountability for the policies adopted. Public institutions should be able to account for established policies taking into account future impacts.

\section{CONCLUSION}

The meaning of accountability can be interpreted as accountability in every organizational activity by the leaders of the organization to the authorizing party. In other words, accountability implies an obligation to present and report any follow-up and its activities in the administrative field to the party providing the response. In this case, the terminology of accountability is seen from the point of view of action control on the achievement of the objectives. Accountability is the main agent when an actor presses or forces another actor to do his will. Broadly concluded that accountability related to the 
obligations of government institutions and the officials who work in it to make policies and perform actions in accordance with the applicable values and needs of society. Public accountability demands a clear and efficient duty restriction of the bureaucratic apparatus. Accountability in this discussion is divided into two types namely vertical accountability and horizontal accountability. In realizing good governance, true accountability is not only limited to financial, economic, but also the responsibility of the government and the people, where the people have the right to judge all actions of the government. Thus the accountability intended in this context is not only to resource accountability but rather to how resources are accounted for accountable.

\section{REFERENCES}

[1] Rasul, Syahrudin, Pengintegrasian Sistem Akuntabilitas Kinerja dan Anggaran dalam Perspektif UU NO. 17/2003 Tentang Keuangan Negara. Jakarta: PNRI, 2003

[2] Frederickson, H. George., The Spirit of Public Administrastion. San Fransisco: Jossey-Bass Publisher, 1997

[3] Paterson dalam Hodge, Graeme, Minding Everybody's Business: Performance Management in Public Sector Agencies. Australia, Melbourne: Montech Pty Ltd, 1993
[4] Sangkala, Journal Administrasi Publik, Vol. V, No. 2, 2009, pp 32.

[5] Mulgan, Richard, Accountability: An Ever Expanding Concept Public Administration, Behn, R.D. 2001, Rethinking Democracy Accountability. Washington, D.C.: Brookings Intitution Press, 2000

[6] Norris, Jessey J, Rethinking accountability in new governance. Inovation: The European Journal of Social Science Research. Vol. 27, No. 3, 2014, pp 205

[7] Sangkala. Loc.it: 29-40, 2009

[8] Sam Agere, Promoting Good Governance: Principles, Practices and Perspectives. London: Commonwealth Secretariat, 2000

[9] O.P. Dwivedi and J.G. Jabbra, "Public Service Responsibility and Accountability", dalam J.G. Jabbra and O.P. Dwivedi, Public Service Accountability: A Comparative Perspective, West Hartford-Connecticut: Kumarian Press, Inc., 1989.

[10] Wibowo, Edi, Dkk, Memahami Good Government Governance dan Good Corporate Governance, 2004

[11] Thoha, Birokrasi dan politik di indonesia. PT Raja Grafindo Persada, Jakarta, 2003

[12] Mardiasmo, Perwujudan Transparansi dan Akuntabilitas Publik Melalui Akuntansi Sektor Publik : Suatu Sarana Good Governance. Jurnal Akuntansi Pemerintahan, 2006

[13] Mahmudi, Manajemen Keuangan Daerah, Jakarta, Penerbit Erlangga., 2010 